\title{
INTERPRSONAL FUNCTIONS OF TABOO WORDS UTTERED BY THE CHARACTERS IN VACATION MOVIE
}

\author{
Bambang Irawan \\ Universitas Pamulang \\ dosen01218@unpam.ac.id
}

\begin{abstract}
This reserached was aimed to figure out the interpersonal functions of taboo words in Vacation movie. Descriptive qualitative method was emploed in this research since the data were non-numerical data and the results of the research were explained in description which can be in forms of words, sentences, discourse, picture, etc. This research employed simak and catat technique to collect the data from Vacation movie. This is a technique for achieving data through listening carefully and then followed by taking note. In this research, the writer did the simak and catat technique by watching and listening to the movie carefully and then noted some words which were categorized as taboo words. Then, the data were analyzed and classified to figure out their interpersonal functions based on the theory of Zhao and Zhang (2016). As the result, there are at least three interpersonal functions of taboo words which are used and uttered by the characters in the Vacation movie. The interpersonal functions of taboo words which are found in the Vacation movie are to strengthen power and intensity, to vent pent-up emotions, and to show the acquaintance and intimacy.
\end{abstract}

Keywords: interpersonal function, language, taboo words, Vacation movie

\section{INTRODUCTION}

The language exists in a society and i cannot be separated from the society in which it is spoken. Language plays a really important role in building interaction in a society because language is a mean of communication. Language is used by people in a society to communicate in order to build social contact which is very essential to build interaction in society. Thus, since it is used to express human views, smotions, and attitudes, language is considered as a part of human social interaction, and it has an essential role to strengthen the relasionship of people in the society since.

Furthermore, language and the context in which the language is used are also inseparable. It means that social factors play the influencing roles in directing language use between the speakers. The way people speak is determined by the social context (Trudgill, 2000: 32). In other words, the social context in which the language is used in an interaction affects the use of language itself. Consequently, social structure, social environment, culture, etc are considered as some aspects that affect the language.

Language is deeply rooted in the culture. Even, in fact it is closely related to the culture (Rahardjo, 2002: 43) since it reflects their norms. Furthermore, langauage is a mean which is used to conduct social live, and it cannot be separated from culture in multiple and complex way (Kramsch (1998: 3). Hence, 
these beliefs should not be ignored to avoid severe assault between speakers because they have to behave appropriately based on the norms in their society. People also should note that all languages have certain words or expressions that are banned to be used in public. The words and expressions are known as taboo words.

Taboo words exist in every language and society as stated by Fairman (2009: 27) that taboo words and taboo acts exist in every society. Taboo acts refer to any activities which are forbidden to do, while taboo words refer to any words that should be avoided in conversation. In addition, Fromkin (2005: 576) points out that taboo is a word that is not to be used at least in a polite society. Allan and Burridge (2006: 27) add that taboo is considered as any behavior that causes injury, harm, or discomfort to an individual or even community. From the statements above, it can be concluded that taboo words are the words that must be avoided in conversation or interaction with an individual or more because they might have bad effects that follow the use of taboo words.

Although taboo words have always been regarded as something forbidden, in fact taboo words are still used in society because every society has different degree of tolerance which is shown toward any taboo behavior (Allan and Buridge, 1991: 105). It means that in certain contexts, the use of taboo words is still tolerable but in certain different context it is not. Today, taboo words can be found in daily conversation, songs, social media, movies, etc. The utilization of taboo words, although they are considered as something forbidden, shows the fact that actually taboo words provide several different functions both personal and interpersonal functions (Trudgill, 2009:155).

The functions of using taboo words in daily life become an interesting social phenomenon. The writer was interested in conducting a research to investigate this phenomenon. The writer focused on finding out the interpersonal functions of using taboo words. The movie entitled "Vacation" was chosen as the object of this research because the characters in the movie utter a lot of taboo words for several different purposes.

Thus, this research was aimed to figure out the interpersonal functions of taboo words uttered by the characters in Vacation movie. This research is worthystudying since it is able to contribute to a greater understanding on the significance of analyzing taboo words.

Taboos in general can be describes as something forbidden that must be avoided in social interactions since they can generate bad effects such as harm, injury or discomfort to individual or society. The term "taboo", which is the first time introduced by Captain Cook, derives from Tongan term "tabu" that refers to a person, object or act that is dangerous and must be avoided (Allan and Burridge, 2006: 2-3). According to Laitinen (2009: 5), anything that is fobidden to do or something that is not spoken can be considered as a taboo. In addition, Hughes (2006: 462) views that nowadays a taboo can be defined as the strong prohibitions againts anything including words, expressions, and topics especially of sexual and racist which are not acceptable in particular community. Thus, from the statements given by the experts above, it is clearly stated that taboo refers to words, expressions, object, and even act that are considered as something forbidden because of the bad effects they generate. Although taboo refers to something forbidden, this research focused only on taboo words.

Taboo words are defined as the words that should be avoided or censored in particular occasion because the speaker worries about offending the listener (Allan and Burridge, 2006: 237-238). Taboo words can be recognized by their characteristics: their impropriety; appalling 
character; lack of morality which are supposed to be avoided in interactions so that other members in society will not be offended (Mbaya, 2002: 224).

Taboo words might have similarities among societies but they are usually vary from society to society or from culture to culture. Le and Le (via Fakuade, 2013: 120) argue that the cultural views and beliefs of a society determine the parameter of taboo from one culture to another that makes the level of prevention of taboo words in language is specific in culture. In line with Le and Le, Akmajian, et al (2004: 303) state that culture usually describes what is considered as taboo. The statements above clearly stated that taboo words are the words which are considered as forbidden words that should be avoided in daily conversation and they related to a specific culture and society. Therefore, people must learn to know what thing they should or should not do in a particular society to avoid misunderstanding or offending someone in interaction.

To determine the types of taboo words is a little bit complicated since a lot of experts propose different types of taboo from different perspectives. One of experts who determines the types of taboo words is Batistella (2005: 72) who suggests that taboo words are classified into four types which are epithets, profanity, vulgarity, and obscenity.

The term "epithet" commonly refers to a word or phrase which characterizes a noun and regularly associated with it (Crystal, 2008: 171). The haunted house and the iron lady are the examples of epithet. However, epithet is not always about good nick name given to characterize a noun. In term of taboo words, epithet refers to the existence of several types of slurs that is commonly related to race, ethnicity, sexuality, one's appearance, and disabilities (Batistella, 2005: 72). The words such as nigger, motherfucker, tit-man, son of a bitch, etc are examples of epithet in term of taboo words.

Profanity is defined as religious cursing since it usually includes the foulmouthed of something sacred (Batistella, 2005: 72). Furthermore, Jay in Doyle (2006: 2-3) argues that profanity is the utilization of religious terms, secular, or uncaring manner as the expression which is used in communication. What needs to be highlighted is that the purpose of profanity is not to vilify God or something related to religion. Profanity is commonly used to express emotional felling to certain motives. The words or phrases such as hell, damn, goddamn, etc are the examples of profanity.

In term of taboo words, sexual anatomy or excretory function which is spoken or expressed in a rough manner is considered as vulgarity (Batistella, 2005: 72). In daily communication, vulgarity is used to humiliate or bring down thing or person referred to (Jay in Mercury, 1995: 30). The words such as ass, dick, tit, cock, etc are considered as the examples of vulgarity.

Similar to vulgarity, the term of obscenity also refers to the words or expressions that contain sexual anatomy, sexual activity, and excretory function that are also uttered in rough manner (Batistella, 2005: 72). The difference between vulgarity and obscenity is that obscenity is commonly uttered to generate repulsive sense, impolite, and detestable to morality. The words such as fuck and shit are considered as the examples of obscenity.

The interpersonal function enacts social relationships, embodies all users of language to express social and personal relations. In communication, no matter what the addresser wants to express and imply, all can be illustrated by the way he chooses according to the context of situation.

According to Zhao and Zhang (2016), there are several interpersonal 
functions of taboo words. First, some words are obviously taboos in common life. Participants in certain settings use those words to strengthen power and intensity. For example, the word "bloody" was used to strengthen the mood and express the narrator's emotion without any intention to offend body individually.

Second, Individuals may use taboo words to vent pent-up emotions such as anger, pressure or frustration, especially when encountering unpleasant, frustrating and irritating situation. If people have stressful occupations or keep staying in stressful condition, they tend to relieve their tensions by using taboo words more. That is also the reason why there is a high degree of taboo word use among these men working on board since such work was quite dangerous and stressful.

Third, as members of social group, the participants in the communication are not isolated individually. One of language's functions is to act as a symbol of a group identity. Linguistic taboo's observance and violation can reveal the relationship between participants in communication. For example, the workers in factories stay together every day and have same social status. Therefore, the relationship is more intimate than others. In daily greeting, certain taboo words are used to show the acquaintance and intimacy.

Vacation is an American comedy film which is produced by New Line Cinema, Bender Spink, and Big Kid Picture and distributed by Warner Bros Picture. This movie was supposed to be released on October $9^{\text {th }}, 2015$ but it was finally released on July $31^{\text {st }}$, 2015. This movie is about Rusty Griswold, a pilot of a low budget regional airline called EconoAir, who is trying to be close again with his wife named Debbie and their two children. Actually Rusty always takes his family to their cabin in Cheboygan, Michigan as their annual trip but he realizes that his wife is not really happy with that kind of trip. So, he decides to take his family to Walley World just like he did with his parents and sister. Instead of having fun, they have to face and experience crazy and unpredictable situations.

\section{METHOD}

This research employed descriptive qualitative because the data were nonnumerical data and the results of the research were explained in description which can be in forms of words, sentences, discourse, picture, etc as Strauss and Corbin (1998: 11) stata that quantification and statistical technique are not used to achieve a qualitative research because it is aimed to give complex details about particular phenomenon which can be overwhelming to be expressed with quatitative method.

According to Bousfield (2008: 15), verbal data which can be found in the utterances spoken by the speakers and nonverbal data such as gestures, facial expression, tone, and physical contact between speakers can be employed in conducting qualitative research.. In this research, the data were taken from dialogues which are spoken by the characters in Vacation movie. The movie itself was downloaded from HOOQ which is an official application that can be downloaded from Play Store.

This research employed simak and catat technique to collect the data from Vacation movie. According to Sudaryanto (1993: 133-135), this is a technique for achieving data through listening carefully and then followed by taking note. In this research, the writer did the simak and catat technique by watching and listening to the movie carefully and then noted some words which were categorized as taboo words. Then, the data were analyzed and classified to figure out their interpersonal functions based on the theory of Zhao and Zhang (2016). 


\section{DISCUSSIONS}

\section{Strengthening Power and Intensity}

Zhao and Zhang (2016: 1962)

highlight that some words are obviously taboos in common life. Participants in certain settings use those words to strengthen power and intensity. This interpersonal function of taboo words is also found in Vacation movie.

\section{Datum 1}

James : "Cut it out!"
Kevin : (Standing up) "Or
what, bitch?"
James sighs and goes back
to his book.
Kevin : (Sits down)
"That's what I thought, bitch"

The dialogue above occurs when James and Kevin sit at the breakfast table. James tries to read a paperback of Kerouac's Dharma Bums while Kevin repeatedly flicks front loops at him with his spoon. Kevin always bullies and bothers James although James is actually his older brother. Kevin uses taboo word to strengthen his power over his older brother.

\section{Datum 2}

$\begin{array}{ll}\text { James } & \text { : "I think this is a } \\ & \text { great idea, Dad. } \\ & \text { Heading out on the } \\ \text { open road, } & \\ & \text { discovering } \\ & \text { America. We'll be } \\ & \text { like Jack Kerouac } \\ & \text { and Merry } \\ & \text { Pranksters!" } \\ \text { Kevin } & \text { : "Don't say weird } \\ \text { shit!" } & \end{array}$

The dialogue above occurs when Rusty informs James and Kevin about his idea to take them to go to Walley World by driving a car. When James explains his opinion about the idea, Kevin responds it by uttering taboo word to make James stop talking. It shows that Kevin dominates his older brother. By uttering taboo word to his older brother, Kevin shows his power and intensity.

\section{Venting Pent-Up Emotions}

As mentioned above that according to Zhao and Zhang (2016: 1962) that Individuals may use taboo words to vent pent-up emotions such as anger, pressure or frustration, especially when encountering unpleasant, frustrating and irritating situation. This interpersonal function of taboo words is also found in Vacation movie.

\section{Datum 3}

$$
\begin{aligned}
& \text { Rusty : "Let me give you a } \\
& \text { hand." } \\
& \text { Passenger : "Can you please } \\
& \text { stay the fuck away from us?" }
\end{aligned}
$$

The dialogue above occurs on the plane which is being flied by Rusty. He comes out from the cockpit and tries to have friendly conversation with the passengers. In the beginning, the conversation runs smoothly. Suddenly the turbulence happens three times and shakes the plane. The first turbulence makes Rusty fall and unintentionally touch the breast of the passenger's wife. The passenger tries to understand the situation and he is not angry with Rusty. When the second turbulence happens and makes Rusty fall again, Rusty intentionally tries to touch the breast of the passenger's wife. The passenger starts to be bothered by Rusty. The third turbulence makes Rusty fall again and unintentionally tear the passenger's wife dress. Finally, the passenger vents his pen-up anger by uttering taboo word.

\section{Datum 4}

$$
\begin{aligned}
& \text { Handsome Pilot : "You are } \\
& \text { people fucking crazy!" } \\
& \text { Rusty : "See you } \\
& \text { around. You piece of ass!" }
\end{aligned}
$$

The conversation above occurs in Walley World when Rusty and his family get involved in a fighting with handsome pilot's family to ride Velociraptor ride in Walley World. The handsome pilot is actually an arrogant pilot who always annoys Rusty. The pilot also often mocks 
Econo-Air in which Rusty works. So, when they meet and fight in Walley World, they show the anger by uttering taboo words.

\section{Datum 5}

College Student : "Wait, are you Debbie Fletcher?"

$\begin{array}{ll}\text { Debbie } & : \text { :Yeah." } \\ \text { College Student } & : \text { “Oh } \underline{\text { my }} \\ & \text { shit. I can't }\end{array}$

believe it's

you. It's

Debbie

fucking

Fletcher!"

This dialogue occurs when Rusty and his family step by Memphis State University in which Debbie studied a couple years ago. Then, they show the students there are conducting a charity event named Tri-Pi Chug Run which was initiated by Debbie. Then a student who has conversation with Debbie is so surprised and happy because she knows that Debbie is the legend of Tri-Pi Chug Run. She shows her happiness by uttering taboo words.

\section{Showing the Acquaintance and Intimacy \\ Zhao and Zhang (2016: 1962) point} out that linguistic taboo's observance and violation can reveal the relationship between participants in communication. For example, the workers in factories stay together every day and have same social status. Therefore, the relationship is more intimate than others. In daily greeting, certain taboo words are used to show the acquaintance and intimacy. This interpersonal function of taboo words was also found in Vacation movie.

\section{Datum 5}

$$
\begin{aligned}
& \text { Rusty : "Is is fun?" } \\
& \text { Jack : "No, it's terrible. } \\
& \text { Of course it's fun. Hot damn, } \\
& \text { it's a go car." }
\end{aligned}
$$

This dialogue occurs in Rusty's house when Jack and his family come to have dinner together in Rusty's house. Then, they talk about go car. When Jack uses taboo words in their conversation, Rusty doesn't get offended because he and Jack are close. Actually, Jack uses taboo words to emphasize that go car is interesting to the person that he knows well. If Jack talks with someone else who is not close to him, Jack probably will not use taboo words because he might iritate him/her.

Datum 6

\section{Debbie : "Tri-Pi, motherfuckers!"}

This utterance is uttered by Debbie when she wants to try Tri-Pi Chug Run. In this community, the use of motherfuckers will not irritate someone else because this is how they greet the other members of the community to show the acquaintance and intimacy. That is why when Debbie utters that, the other members hail her instead of being irritated.

\section{CONCLUSION}

Taboo words, as a part of language, are closely related to the culture of a society and the specific context in which they are used. Although taboo words are commonly avoided, they actually have some interpersonal functions.

This research was aimed to figure out the interpersonal functions of taboo word in Vacation movie. Based on the explanation that have been explained in the findings and discussions section, it can be concluded that there are at least three interpersonal functions of taboo words which are used and uttered by the characters in the Vacation movie. The interpersonal functions of taboo words which are found in the Vacation movie are to strengthen power and intensity, to vent pent-up emotions, and to show the acquaintance and intimacy.

\section{REFERENCES}

Akmajian, A., R. Demers, Farner, A., \& Harnish R. (2004). Linguistics: 
An Introduction to Language and Communication. New Delhi: Prentice Hall.

Allan, K \& Burrudge, K. (1991). Euphemism, Dysphemism, and Cross-Varietals Synonymy. New York: New Burry House Publisher.

Allan, K. and Burridge, K. (2006). Forbidden Words: Taboo and the Censoring of Language. New York: Cambridge University Press.

Batistella, E.L. (2005). Bad Language: Are Some Words Better Than Others?. New York: Oxford University Press.

Bousfield, D. (2008). Impoliteness in Interaction: Pragmatics and Beyond New Series. Amsterdam: John Benjamins Publishing Company.

Fairman, C.M. (2009). Fuck: Word Taboo and Protecting Our First Amandment Liberties. Illinois: Sphinx Publishing.

Fakuade, G., Kemdirim, N., Nnaji, I., \& Nwosu, F. (2013). "Linguistic Taboos In The Igbo Society: A Sociolinguistic Investigation". Journal of Language, Discourse \& Society, 2, 2, 117-132.

Fromkin, V. (2005). An Introduction to Language. USA: Thompson Corporation.
Kramsch, C. (1998). English Introduction to Language and Culture. UK and New York: University Press

Mbaya, N. (2002). "Linguistic Taboo in African Marriage Context: A Study of Oromo Laguu". Nordic Journal of African Studies.11, 224-235

Mercury, R.E. (1995). "Swearing: A Bad Part of Language; A Good Part of Lanugage Learning". TESL Canada Journal, 13, 1, 28-36.

Rahardjo, M. (2002). Pengantar Penelitian Bahasa. Malang: Cendikia Parahayu.

Rahardjo, M. (2002). Relung-Relung Bahasa. Yogyakarta: Aditia Media.

Strauss, A. and Corbin, J. (1998). Basic of Qualitative Research: Second Edition: Techniques and Procedures for Developing Grounded Theory. California: SAGE Publication, Inc.

Sudaryanto. (1993). Metode dan Aneka Teknik Analisis Bahasa. Yogyakarta: Duta Wacana University Press.

Trudgill, P. (2000). Sociolinguistics: An Introduction to Language and Society (Fourth Edition). London: Penguin Group. 